\title{
Effect of Sucralose on Glucose Uptake in Rat L6 Myotubes
}

\author{
${ }^{1}$ Shubha N Prakash, ${ }^{2}$ Jayakumari Shanthakumari, ${ }^{3}$ Anitha Devanath
}

\begin{abstract}
Introduction: With growing awareness of the link between diet and health and the problem of obesity, public concern over sugar levels in the diet is forcing a worldwide trend toward cutting down on sugar by using artificial sweeteners (AS).
\end{abstract}

Aim: To study the effect of increasing concentrations of sucralose (an AS) on glucose uptake in rat L6 myotubes.

Materials and methods: The L6 cell line from American type cell culture (ATCC) was grown in Dulbecco's Modified Eagle's Medium (DMEM) and differentiated into myotubes. The wells were exposed to either $0,1 \mathrm{nM}, 1 \mu \mathrm{M}$, or $1 \mathrm{mM}$ of sucralose alone or with $10 \mathrm{nM}$ insulin for 24 hours. Glucose uptake was studied after this period.

Results: Significant decrease was seen between the insulinstimulated basal glucose uptake and insulin-stimulated glucose uptake across all the concentrations of sucralose treatment.

Conclusion: Increased concentration of sucralose appears to decrease glucose uptake even on insulin stimulation.

Clinical significance: It may not be beneficial to use sucralose in certain groups of people who have insulin resistance or are prone to it.

Keywords: Artificial sweetener, Glucose uptake, Sucralose.

How to cite this article: Prakash SN, Shanthakumari J, Devanath A. Effect of Sucralose on Glucose Uptake in Rat L6 Myotubes. Indian J Med Biochem 2017;21(2):162-165.

Source of support: Nil

Conflict of interest: None

\section{INTRODUCTION}

The use of low-calorific/noncalorific/AS as substitutes for sugar has increased markedly in the past decades, reflecting widespread attempts to reduce energy consumption and combat the rising prevalence of obesity. ${ }^{1}$ These sweeteners are 30 to 13,000 times sweeter than table sugar. These sugar substitutes are used in a variety of food substances labeled as "diet" or "sugar free"

\footnotetext{
${ }^{1}$ Assistant Professor, ${ }^{2}$ Professor Grade II, ${ }^{3}$ Professor

${ }^{1-3}$ Department of Biochemistry, St. John's Medical College Bengaluru, Karnataka, India

Corresponding Author: Jayakumari Shanthakumari, Professor Grade II, Department of Biochemistry, St. John's Medical College Bengaluru, Karnataka, India, Phone: +919880259248, e-mail: jaya_kripal@yahoo.com
}

including candy, chewing gum, ice cream, soft drinks, jellies, yogurt, fruit juice, and baked goods. They are also present in some pharmaceutical products, which include cough drops, cough syrups, certain medications, and vitamins. ${ }^{2}$ Health awareness and adopting "healthier" diets in the quest to quell metabolic disorders and diseases are increasing. ${ }^{3}$ People who are overweight/obese or diabetics consume these substances to control their dietary intake of table sugar and body weight. ${ }^{2}$ However, several common AS, e.g., aspartame, sucralose, and saccharin, have been the subjects of enduring controversy due to observational and laboratory studies indicating an association of AS consumption with increased appetite, food intake, weight gain, and glucose intolerance. ${ }^{1,4-6}$ It is still debatable whether increased AS or nonnutritive sweetener (NNS) consumption has any adverse effects on obesity and diabetes management. ${ }^{2,7-9}$

Sucralose is an intensely sweet compound that has a sweetening potency approximately 600 times that of sucrose. Unlike sugar, the glycosidic linkage of this substituted disaccharide is apparently unavailable to the enzymes that cleave it. Ingested sucralose is neither metabolized to its monosaccharide-like moieties nor is it a source of energy. Therefore, it is not digested and about 15 to $20 \%$ is absorbed as such and completely excreted within 72 hours in urine. Its acceptable daily intake (ADI) is 0 to $15 \mathrm{mg} / \mathrm{kg} / \mathrm{d} \cdot{ }^{10}$ Sucralose undergoes thermal decomposition above $119^{\circ} \mathrm{C}$ and forms chloropropanols with glycerol, which are carcinogenic. ${ }^{11}$ However, it is used in beverages and other foods, including those undergoing heat treatments, such as baked goods. Data from some studies, conducted in human subjects with and without diabetes, found that even extremely high doses of sucralose (many times above the ADI) did not have adverse effects. ${ }^{12-19}$ However, some other studies found weight gain and metabolic disturbances. ${ }^{4,5,20-22}$

Suez et $\mathrm{al}^{23}$ have shown that consumption of AS can lead to glucose intolerance. Pepino et $\mathrm{al}^{24}$ in a review have shown that, in obese individuals, sucralose affects the glycemic response to an oral glucose load and increases both peak plasma glucose concentration and insulin secretion in response to glucose stimulation. Alonso Romo-Romo et $\mathrm{al}^{25}$ in a systematic review, have observed that obesity could be a possible confounding factor for the associations found in some of the observational studies bwtween NNS consumption and the development of metabolic diseases. 
They also suggested that further studies are required to probe the effect of AS on carbohydrate metabolism.

Therefore, we wanted to study the effect of sucralose on glucose uptake in muscle cells. We selected rat L6 cells as this cell line has shown to be most sensitive to insulin.

\section{AIM}

To study the effect of sucralose on glucose uptake in L6 cell line.

\section{MATERIALS AND METHODS}

\section{Cell Culture}

The L6 cells from the ATCC were grown in DMEM with $4 \mathrm{mM}$ L-glutamine adjusted to contain $1.5 \mathrm{~g} / \mathrm{L}$ sodium bicarbonate, $1 \mathrm{~g} / \mathrm{L}$ glucose, and $1 \mathrm{mM}$ sodium pyruvate (Gibco) with $10 \%$ fetal bovine serum (FBS) in an incubator at $37^{\circ} \mathrm{C}$ with $5 \% \mathrm{CO}_{2}$. Medium was changed every 2 to 3 days. Once the myoblasts were grown to confluence in a 24-well plate, the media were replaced with DMEM containing $2 \%$ FBS to induce differentiation into myotubes. Full differentiation took about 7 to 8 days. A day prior to experiment, half of the plates (12 wells) were incubated with $0,1 \mathrm{nM}, 1 \mu \mathrm{M}$, or $1 \mathrm{mM}$ of sucralose alone and another half with the increasing concentration of sucralose and $10 \mathrm{nM}$ insulin for 24 hours. After this incubation, glucose uptake was studied.

\section{Glucose Uptake}

All experiments were done in triplicate. After 24-hour incubation with AS, L6 myotubes were incubated with deoxyglucose in no-glucose DMEM media for 10 minutes. After 10 minutes, $0.1 \mu \mathrm{Ci} / \mathrm{mL}$ 2-deoxy[3H] glucose (PerkinElmer Life Sciences) was added alone for basal and with $10 \mathrm{nM}$ insulin for stimulated glucose uptake. 10 minutes later, L6 myotubes were placed on ice, washed with ice-cold phosphate buffered saline, and lysed in $0.1 \%$ sodium dodecyl sulfate. It was then transferred to vials with scintillation cocktail for counting and an aliquot taken for protein estimation by Bicinchoninic acid method (ThermoFisher Pierce). Uptake of 2-deoxyglucose was then quantified by liquid scintillation counter and expressed per mg of protein.
Table 1: Two-way ANOVA test between insulin-stimulated and AS-induced glucose uptake $(p<0.05)$

\begin{tabular}{llr}
\hline & \% variation & $p$-value \\
\hline Interaction & 12.23 & 0.0137 \\
Sweetener & 52.30 & $<0.0001$ \\
\hline
\end{tabular}

\section{RESULTS}

The results were analyzed using GraphPad Prism software version 6. Two-way analysis of variance (ANOVA) and Bonferroni's multiple comparison were done.

Table 1 depicts two-way ANOVA that showed a significant difference ( $p$ 0.0137) for the interaction between sweetener and insulin and $(\mathrm{p}<0.0001)$ for the effect of different concentrations of sucralose on glucose uptake.

Table 2 depicts Bonferroni's multiple comparison tests. There was significant increase in stimulated untreated glucose uptake compared with basal untreated uptake. Significant decrease was also observed between stimulated untreated $v$ s stimulated sucralose of $1 \mathrm{nM}, 1 \mu \mathrm{M}$, and $1 \mathrm{mM}$ glucose uptake. Our study shows an increasing suppression of glucose uptake as sucralose concentration was increased.

Graph 1 shows basal and stimulated glucose uptake vs different concentrations of sucralose.

\section{DISCUSSION}

The AS act through a sweet-taste receptor, which is a transmembrane protein present in the cell membrane, i.e., coupled to a G-protein. It is a dimer of T1R2 and T1R3 proteins. It is present in tongue and other nongustatory sites like intestine, brain, adipocytes, muscle, etc. Binding of a sweet compound to the receptor causes dissociation of $\alpha$-gustducin from the receptor and activates phospholipase $C-\beta 2$. Elevation of cytoplasmic calcium concentration $[\mathrm{Ca} 2+]_{\mathrm{i}}$ and subsequent activation of sodium-permeable TRPM5 channel are critical to sweet sensation. Stimulation of the T1R2/T1R3 taste receptor activates peripheral gustatory nerves and, in turn, brain gustatory pathways. Sweet-tasting compounds, such as sugars and low-energy sweeteners, can bind to and stimulate the sweet-taste receptor. ${ }^{26}$ Nakagawa et $\mathrm{al}^{27}$ have studied the mechanism of action of four different AS including sucralose in MIN6

Table 2: Bonferroni's multiple comparison test for untreated stimulated vs stimulated sucralose conditions

\begin{tabular}{|c|c|c|c|c|c|}
\hline & Mean 1 & Mean 2 & $\begin{array}{l}\text { Mean } \\
\text { difference }\end{array}$ & $\begin{array}{l}95 \% \text { Cl of } \\
\text { difference }\end{array}$ & $\begin{array}{l}\text { Significance } \\
(p<0.05)\end{array}$ \\
\hline Basal untreated vs stimulated untreated & 21.25 & 28.5 & -7.25 & $-10.46-0.7939$ & Yes \\
\hline Stimulated untreated vs stimulated sucralose $1 \mathrm{nM}$ & 28.5 & 18.2 & 10.3 & $3.065-14.87$ & Yes \\
\hline Stimulated untreated $v s$ stimulated sucralose $1 \mu \mathrm{M}$ & 28.5 & 17.67 & 10.83 & $3.873-15.13$ & Yes \\
\hline Stimulated untreated vs stimulated sucralose $1 \mathrm{mM}$ & 28.5 & 15.4 & 13.1 & $5.865-17.67$ & Yes \\
\hline
\end{tabular}

$\mathrm{Cl}$ : Confidence interval 


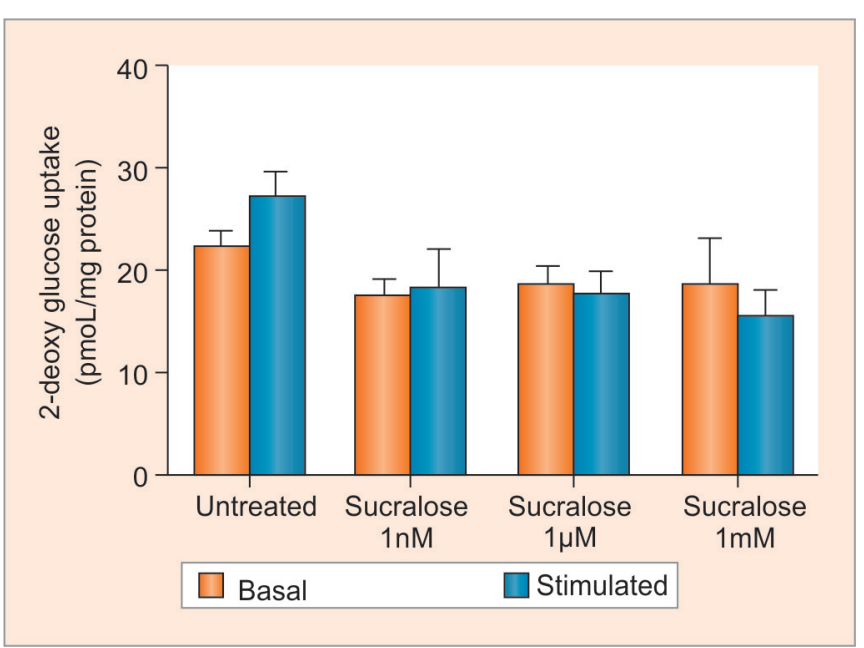

Graph 1: Glucose uptake vs AS concentration in basal and stimulated (insulin) conditions

cells. They have found that all the four AS evoke different cellular responses and were inhibited by different substances. Sucralose induced elevation of $[\mathrm{Ca} 2+]_{\mathrm{i}}$ and $[\mathrm{cAMP}]_{\mathrm{i}}$ and was inhibited by gurmarin, an antagonist of the sweet-taste receptor. Masubuchi et $\mathrm{al}^{28}$ have shown that the sweet-taste receptor in 3T3 L1 cells was distinct from the one seen in tongue and may activate a different signaling pathway. Simon et $\mathrm{al}^{29}$ have shown that these AS can act even in T1R2/T1R3 knockdown cells. This implies that they could be acting through other receptors that have not yet been identified.

In our study, we observed that sucralose decreased glucose uptake in insulin-stimulated condition across all the concentrations studied. This suppression of uptake increased with increase in concentration of sucralose as shown in Graph 1. This is in accordance with Suez et $\mathrm{al}^{23}$ and Pepino et $\mathrm{al}^{24}$ who suggest that AS could cause insulin resistance in human subjects. Pepino et $\mathrm{al}^{24}$ found that ingestion of sucralose affects the glycemic response to an oral glucose load and increases both peak plasma glucose concentration and glucose-stimulated insulin secretion in subjects with obesity. Sucralose also tended to increase plasma glucose-dependent insulinotropic peptide concentration, and could promote insulin resistance. Approximately $20 \%$ higher than normal concentrations of insulin were required to maintain same glycemia when obese subjects consumed sucralose than when they consumed water before glucose ingestion. Sucralose has been shown to increase glucose-stimulated insulin secretion in mouse insulinoma-MIN6 cell line and mouse and rat islet cells. ${ }^{30,31}$ It also increased secretion of glucagonlike polypeptide- 1 in human L cell line NCI-H716. ${ }^{30}$

There are several studies on the effect of sucralose and other AS in various other cell lines. But we found studies with effect of other AS on glucose uptake. In a study done by Simon et al, ${ }^{29}$ saccharin AS increased adipogenesis and glucose uptake in 3T3L1 adipocytes, but sucralose caused mild inhibition of adipogenesis. They studied 0.45 and $4.5 \mathrm{mM}$ saccharin concentrations, which are greater than the expected physiological concentration (approximately $75 \mu \mathrm{M})$, and these concentrations are much higher than what we have used in our study. Bhasker et al ${ }^{32}$ reported increased glucose uptake with naturally occurring AS in diabetes-induced L6 cells. These differences could be attributed to the difference in cell type (3T3L1 and diabetes-induced L6) and/or the type of AS and/or mode of action through different receptors. Therefore, further studies are required to elucidate the receptor and signaling pathways for sucralose.

\section{CONCLUSION}

From our study, we have seen a decrease in insulinstimulated glucose uptake with sucralose. Increase in concentration of sucralose decreased the uptake further. Hence, it may not be beneficial to use sucralose in certain groups of people who have insulin resistance or are prone to it.

\section{ACKNOWLEDGMENT}

Authors would like to thank Prof Matthew Watt for support, encouragement, and infrastructure to carry out the work in his Biology of Lipid Metabolism laboratory, Department of Physiology, Monash University, Melbourne.

\section{REFERENCES}

1. Overduin J, ColletTH,Medic N,Henning E, KeoghJM,Forsyth F, Stephenson C, Kanning MW, Ruijschop RM, Farooqi IS, et al. Failure of sucrose replacement with the non-nutritive sweetener erythritol to alter GLP-1 or PYY release or test meal size in lean or obese people. Appetite 2016 Dec;107:596-603.

2. van Eyk AD. The effect of five artificial sweeteners on $\mathrm{CaCO}_{2}, \mathrm{HT}-29$ and HEK-293 cells. Drug Chem Toxicol 2015 Oct;38(3):318-327.

3. Sharma A, Amarnath S, Thulasimani M, Ramaswamy S. Artificial sweeteners as a sugar substitute: are they really safe? Indian J Pharmacol 2016 May-Jun;48(3):237-240.

4. Dhingra R, Sullivan L, Jacques PF, Wang TJ, Fox CS, Meigs JB, D'Agostino RB, Gaziano JM, Vasan RS. Soft drink consumption and risk of developing cardiometabolic risk factors and the metabolic syndrome in middle-aged adults in the community. Circulation 2007 Jul;116(5):480-488.

5. Fowler SP, Williams K, Resendez RG, Hunt KJ, Hazuda HP, Stern MP. Fueling the obesity epidemic? Artificially sweetened beverage use and long-term weight gain. Obesity (Silver Spring) 2008 Aug;16(8):1894-1900.

6. Fowler SP, Williams K, Hazuda HP. Diet soda intake is associated with long-term increases in waist circumference in a biethnic cohort of older adults: the San Antonio Longitudinal Study of Aging. J Am Geriatr Soc 2015 Apr;63(4):708-715.

7. Gallus S, Scotti L, Negri E, Talamini R, FranceschiS, Montella M, Giacosa A, Dal Maso L, La Vecchia C. Artificial sweeteners and 
cancer risk in a network of case-control studies. Ann Oncol 2007 Jan;18(1):40-44.

8. Renwick AG. The intake of intense sweeteners - an update review. Food Addit Contam 2006 Apr;23(4):327-338.

9. Tandel KR. Sugar substitutes: health controversy over perceived benefits. J Pharmacol Pharmacother 2011 Oct;2(4): 236-243.

10. Magnuson BA, Carakostas MC, Moore NH, Poulos SP, Renwick AG. Biological fate of low-calorie sweeteners. Nutr Rev 2016 Nov;74(11):670-689.

11. Schiffman SS, Rother KI. Sucralose, a synthetic organochlorine sweetener: overview of biological issues. J Toxicol Environ Health B Crit Rev 2013 Sep;16(7):399-451.

12. Mezitis NH, Maggio CA, Koch P, Quddoos A, Allison DB, Pi-Sunyer FX. Glycemic effect of a single high oral dose of the novel sweetener sucralose in patients with diabetes. Diabetes Care 1996 Sep;19(9):1004-1005.

13. Grotz VL, Henry RR, McGill JB, Prince MJ, Shamoon H, Trout JR, Pi-Sunyer FX. Lack of effect of sucralose on glucose homeostasis in subjects with type 2 diabetes. J Am Diet Assoc 2003 Dec;103(12):1607-1612.

14. Baird IM, Shephard NW, Merritt RJ, Hildick-Smith G. Repeated dose study of sucralose tolerance in human subjects. Food Chem Toxicol 2000 Feb;38(Suppl 2):S123-S129.

15. Ma J, Chang J, Checklin HL, Young RL, Jones KL, Horowitz M, Rayner CK. Effect of the artificial sweetener, sucralose, on small intestinal glucose absorption in healthy human subjects. Br J Nutr 2010 Sep;104(6):803-806.

16. Ford HE, Peters V, Martin NM, Sleeth ML, Ghatei MA, Frost GS, Bloom SR. Effects of oral ingestion of sucralose on gut hormone response and appetite in healthy normal-weight subjects. Eur J Clin Nutr 2011 Apr;65(4):508-513.

17. Wu T, Zhao BR, Bound MJ, Checklin HL, Bellon M, Little TJ, Young RL, Jones KL, Horowitz M, Rayner CK. Effects of different sweet preloads on incretin hormone secretion, gastric emptying, and postprandial glycemia in healthy humans. Am J Clin Nutr 2012 Jan;95(1):78-83.

18. Brown AW, Bohan Brown MM, Onken KL, Beitz DC. Shortterm consumption of sucralose, a nonnutritive sweetener, is similar to water with regard to select markers of hunger signaling and short-term glucose homeostasis in women. Nutr Res 2011 Dec;31(12):882-888.

19. Wu T, Bound MJ, Standfield SD, Bellon M, Young RL, Jones KL, Horowitz M, Rayner CK. Artificial sweeteners have no effect on gastric emptying, glucagon-like peptide-1, or glycemia after oral glucose in healthy humans. Diabetes Care 2013 Dec;36(12):e202-e203.

20. Stellman SD, Garfinkel L. Artificial sweetener use and one-year weight change among women. Prev Med 1986 Mar;15(2):195-202.
21. Colditz GA, Willett WC, Stampfer MJ, London SJ, Segal MR, Speizer FE. Patterns of weight change and their relation to diet in a cohort of healthy women. Am J Clin Nutr 1990 Jun;51(6):1100-1105.

22. Duffey KJ, Popkin BM. Adults with healthier dietary patterns have healthier beverage patterns. J Nutr 2006 Nov;136(11): 2901-2907.

23. Suez J, Korem T, Zeevi D, Zilberman-Schapira G, Thaiss GA, Maza O, Israeli D, Zmora N, Gilad S, Weinberger A, et al. Artificial sweeteners induce glucose intolerance by altering the gut microbiota. Nature 2014 Oct;514(7521):181-186.

24. Pepino MY, Tiemann CD, Patterson BW, Wice BM, Klein S. Sucralose affects glycemic and hormonal responses to an oral glucose load. Diabetes Care 2013 Sep;36(9):2530-2535.

25. Romo-Romo A, Aguilar-Salinas CA, Brito-Córdova GX, Gómez Díaz RA, Vilchis Valentín D, Almeda-Valdes P. Effects of the non-nutritive sweeteners on glucose metabolism and appetite regulating hormones: systematic review of observational prospective studies and clinical trials. PLoS One 2016 Aug;11(8):e0161264.

26. Renwick AG, Molinary SV. Sweet-taste receptors, low-energy sweeteners, glucose absorption and insulin release. Br J Nutr 2010 Nov;104(10):1415-1420.

27. Nakagawa $Y$, Nagasawa M, Mogami H, Lohse M, Ninomiya $Y$, Kojima I. Multimodal function of the sweet taste receptor expressed in pancreatic $\beta$-cells: generation of diverse patterns of intracellular signals by sweet agonists. Endocr J 2013 Aug;60(10): 1191-1206.

28. Masubuchi Y, Nakagawa Y, Ma J, Sasaki T, Kitamura T, Yamamoto Y, Kurose H, Kojima I, Shibata H. A novel regulatory function of sweet taste-sensing receptor in adipogenic differentiation of 3T3-L1 cells. PLoS One 2013 Jan;8(1):e54500.

29. Simon BR, Parlee SD, Learman BS, Mori H, Scheller EL, Cawthorn WP, Ning X, Gallagher K, Tyrberg B, Assadi-Porter FM, et al. Artificial sweeteners stimulate adipogenesis and suppress lipolysis independently of sweet taste receptors. J Biol Chem 2013 Nov;288(45):32475-32489.

30. Jang HJ, Kokrashvili Z, Theodorakis MJ, Carlson OD, Kim BJ, ZhouJ,KimHH,XuX,ChanSL,JuhaszovaM, etal.Gut-expressed gustducin and taste receptors regulate secretion of glucagonlike peptide-1. Proc Natl Acad Sci U S A 2007 Sep;104(38): 15069-15074.

31. Nakagawa Y, Nagasawa M, Yamada S, Hara A, Mogami H, Nikolaev VO, Lohse MJ, Shigemura N, Ninomiya Y, Kojima I. Sweet taste receptor expressed in pancreatic ß-cells activates the calcium and cyclic AMP signaling systems and stimulates insulin secretion. PLoS One 2009 Apr;4(4):e5106.

32. Bhasker S, Madhav H, Chinnamma M. Molecular evidence of insulinomimetic property exhibited by steviol and stevioside in diabetes induced L6 and 3T3L1 cells. Phytomedicine 2015 Oct;22(11):1037-1044. 